\title{
The Role of Plant Breeding Under Changing Climate
}

\author{
Zewdu Asrat \\ Chiro National Sorghum Research and Training Center Chiro. Ethiopian Institute of Agricultural Research, \\ Addis Ababa, Ethiopia
}

\begin{abstract}
Climate change is now unequivocal, particularly in terms of increasing temperature, increasing $\mathrm{CO} 2$ concentration, widespread melting of snow and ice and rising global average sea level, while the increase in the frequency of drought is very probable but not as certain. Even though climate change is one of the major current global concerns, it is not new. Several climate Changes have occurred before, with dramatic consequences in history. Plant breeding is the activity of developing diverse plant varieties that can contribute usefully to cropping and production systems. These breeding efforts are directed at plant improvement. But 'improvement' is a subjective and relative goal and it is useful to regularly break up plant breeding objectives and procedures into clearly defined and manageable units. Owing to the imperatives of food security, plant breeding must combine the objective of ecological intensification with that of adaptation to overall societal and global changes.
\end{abstract}

Keywords: Climate change, Green revolution, Genetic gain

DOI: $10.7176 / \mathrm{JBAH} / 11-4-04$

Publication date: February $28^{\text {th }} 2021$

\section{INTRODUCTION}

Climate change is projected to reduce yield growth rates in much of the world, especially in tropical regions. The Intergovernmental Panel on Climate Change (IPCC,2007) reported that climate change might reduce yields per hectar of wheat, rice, and maize by up to 2 percent per decade starting 2030 compared with projected yields without climate change. Many regions will face increased water stress because of rising competition for water resources and altered precipitation patterns linked to climate change. Furthermore, except in Africa, fertilizer application is already at or above agronomically or environmentally sustainable levels and many regions have maximized their use of irrigation.

Global change occurs at such scales and speeds that agricultural systems could respond by replacing species rather than by seeking better adapted varieties of the usual species. Therefore, it is also necessary to foresee the evolution of a 'portfolio' of species used in target regions. The likely increase in diversity and turnover of ecological, agronomic and socio-economic situations for each species raises the question of which varietal deployment strategy to be select.

Plant breeding is the activity of developing diverse plant varieties that can contribute usefully to cropping and production systems. These breeding efforts are directed at plant improvement. But 'improvement' is a subjective and relative goal and it is useful to regularly break up plant breeding objectives and procedures into clearly defined and manageable units. Owing to the imperatives of food security, plant breeding must combine the objective of ecological intensification with that of adaptation to overall societal and global changes.

The so-called "genetic gain" must not only consider the benefits reaped by a farmer using an improved variety at the level of his/her plot, but also its expected economic, social and environmental impacts on a larger scale in the event of a wider dissemination of this variety. Plant breeding is also a business which must ensure a 'return on investment' and produce goods (new varieties) that ensure a convergence of interests of different economic stakeholders.

Biological sciences are going to strengthen the foundation for plant breeding. After diffuse domestication of crops, the integration of science into formerly empirical breeding coincided with the emergence of genetics and heredity. Applied in concert with a spirit of industrialization, it led to the emergence of a whole plant breeding sector of economic activity and enabled the 'Green Revolution'. Therefore the objective of this review paper is to highlight the role of plant breeding under changing climate.

\section{LITERATURE REVIEW}

\subsection{Climate Changes in History}

Even though climate change is one of the major current global concerns, it is not new. Several climate Changes have occurred before, with dramatic consequences. Among them is the decrease in $\mathrm{CO} 2$ content, which took place 350 million years ago and which is considered to be responsible for the appearance of leaves - the first plants were leafless and it tooks 40-50 million years for leaves to appear (Beerling et al. 2001).

The second climate change was that induced by perhaps the most massive volcanic eruption in Earth history, which took place during the end-Permian (about 250 million years ago) in Siberia when up to 4 million $\mathrm{km}^{3}$ of lava erupted onto the Earth's surface (Beerling 2007). The remnants of that eruption today cover an area of 5 
million $\mathrm{km}^{2}$. This massive eruption caused, directly or indirectly through the formation of organ halogens, a worldwide depletion of the ozone layer. The consequent burst of ultraviolet radiation explains why the peak eruption phase coincides with the timing of the mass extinction that wiped out 0.95 of all species (Beerling 2007).

The third major climate change was the end of the last ice age (between 15000 and 13500 years ago), with the main consequence that much of the earth became subject to long dry seasons. This created favorable conditions for annual plants which can survive dry seasons either as dormant seeds or as tubers. This eventually led to agriculture as we know it today, in the Fertile Crescent, around 11000 years ago, and soon after in other areas.

The fourth climate change is the so-called Holocene flooding, which took place about 9000 years ago and is now believed to be associated with the final collapse of the ice sheet, resulting in a global sea level rise of up to $1.4 \mathrm{~m}$ (Turney \& Brown 2007). Land lost from rising sea levels drove mass migration to the North West and this could explain how domesticated plants and animals, which by then had already reached modern Greece, started moving towards the Balkans and eventually into Europe.

During the last 5000 years, drought, or more generally limited water availability, has historically been the main factor limiting crop production. Water availability has been associated with the rise of multiple civilizations, while drought has caused the collapse of empires and societies such as the Akkadian Empire (Mesopotamia, c. 6200 years ago), the Classic Maya (Yucatan Peninsula, c. 1400 years ago), the Moche IV-V Transformation (coastal Peru, c. 1700 years ago) (de Menocal 2001) and the early bronze society in the southern part of the Fertile Crescent (Rosen 1990).

Projections to the year 2100 indicate that $\mathrm{CO} 2$ emissions are expected to increase by $400 \%$ and $\mathrm{CO} 2$ atmospheric concentration is expected to increase by 100\% (Fig. 1, modified from Cline 2007). Some studies have predicted increasingly severe future impacts with potentially high extinction rates in natural ecosystems around the world (Williams et al. 2003; Thomas et al. 2004).

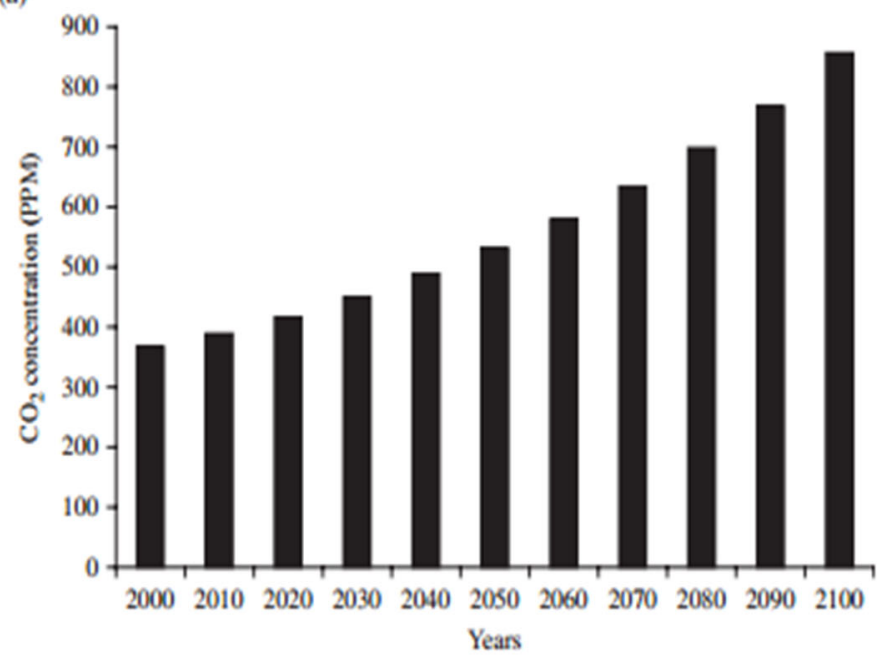

(b)

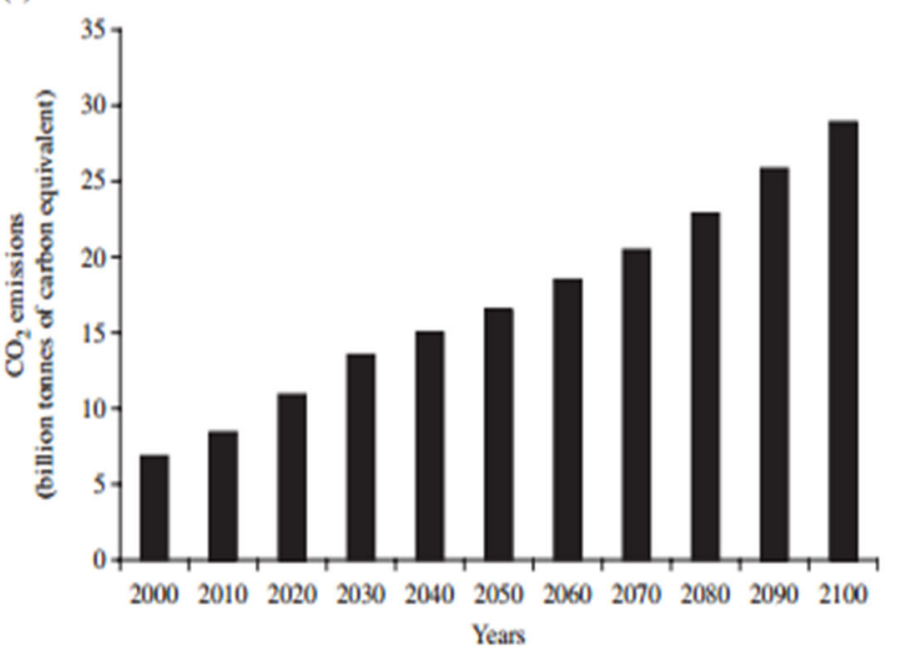

Fig. 1. Projected atmospheric $\mathrm{CO}_{2}$ concentration in parts per million of $\mathrm{CO}_{2}(a)$ and projected emission in billion tonnes of carbon equivalent (b) (modified from Cline 2007). 


\subsection{Climate Changes, Food and Agriculture}

Using the results from formal economic models, it is estimated (Stern 2005) that, in the absence of effective counteraction, the overall costs and risks of climate change will be equivalent to a $5 \%$ decrease in global gross domestic product (GDP) each year. The majority of the world's rural poor (about 370 million of the poorest people on the planet) live in areas that are resource-poor, highly heterogeneous and risk-prone.

The worst poverty is often located in arid or semi-arid zones, and in mountains and hills that are ecologically vulnerable (Conway 1997). In many countries, more people, particularly those at lower-income levels, are now forced to live in marginal areas (i.e. floodplains, exposed hillsides, arid or semiarid lands), putting them at risk from the negative impacts of climate variability and change.

Climate changes are predicted to have adverse impacts on food production, food quality (Atkinson et al. 2008) and food security. One of the most recent predictions (Tubiello \& Fischer 2007) is that the number of undernourished people would have increased by $150 \%$ in the Middle East and North Africa and by $300 \%$ in subSaharan Africa by the year 2080, compared to 1990 (Table 1).

Table 1. Expected number of undernourished in millions, incorporating the effect of climate (data taken from Tubiello \& Fischer 2007).

\begin{tabular}{lrrrrc}
\hline \hline & 1990 & 2020 & 2050 & 2080 & $\begin{array}{c}2080 / \\
1990\end{array}$ \\
\hline $\begin{array}{l}\text { Developing } \\
\text { countries }\end{array}$ & 885 & 772 & 579 & 554 & $0 \cdot 6$ \\
$\begin{array}{l}\text { Asia, developing } \\
\text { Sub-Saharan Africa }\end{array}$ & 659 & 390 & 123 & 73 & $0 \cdot 1$ \\
$\begin{array}{l}\text { Latin America } \\
\begin{array}{l}\text { Middle East and } \\
\quad \text { North Africa }\end{array}\end{array}$ & 54 & 53 & 359 & 410 & $3 \cdot 0$ \\
\hline
\end{tabular}

Agriculture is extremely vulnerable to climate change. Higher temperatures eventually reduce crop yields without discouraging weed, disease and pest challenges. Changes in precipitation patterns increase the likelihood of short-term crop failures and long-term declines in production. Although there will be gains in some crops in some regions of the world, the overall impact of climate change on agriculture is expected to be negative, threatening global food security (Nelson et al. 2009)

Food insecurity would probably increase under climate change, unless early warning systems and development programmes are used more effectively (Brown \& Funk 2008). Currently, millions of hungry people subsist on what they produce. If climate change reduces production while populations increase, there is likely to be more hunger. Lobell et al. (2008) showed that increasing temperatures and declining precipitation over semiarid regions are likely to reduce yields of maize, wheat, rice and other primary crops in the next two decades. These changes could have a substantial negative impact on global food security.

In addition, the impacts of climate change include reductions in calorie consumption and increases child malnutrition. Thus, aggressive agricultural productivity investments are needed to raise calorie consumption enough to offset the negative impacts of climate change on the health and well being of children (Nelson et al. 2009).

\subsection{How do Crops respond to Climate Changes?}

Adapting crops to climate changes has become an urgent challenge which requires some knowledge on how crops respond to those changes. In fact, plants have responded to increasing $\mathrm{CO} 2$ concentration from pre-industrial to modern times by decreasing stomatal density - reversing the change described earlier which led to the appearance of leaves - as shown by the analysis of specimens collected from herbaria over the past 200 years (Woodward 1987).

In Arabidopsis thaliana, the ability to respond to increasing $\mathrm{CO} 2$ concentration with a decrease in the number of stomata is under genetic control (Gray et al. 2000); with the dominant allele (HIC=high carbon dioxide) preventing changes in the number of stomata. In the presence of the recessive hic allele, there is an increase of up to $42 \%$ in stomatal density in response to a doubling of CO2. Stomatal density varies widely within species: for example, in barley, stomatal density varies from 39 to 98 stomata $/ \mathrm{mm}^{2}$ (Miskin \& Rasmusson 1970) suggesting that the crop has the capacity to adapt.

Currently, it is fairly well known how plants respond to an increase in $\mathrm{CO} 2$ concentration, which has both direct and indirect effects on crops. Direct effects (also known as CO2-fertilization effects) are those affecting crops by the presence of $\mathrm{CO} 2$ in ambient air, which is currently sub-optimal for C3-type plants like wheat and barley.

In fact, in C3 plants, mesophyll cells containing ribulose-1,5-bisphosphate carboxylase-oxygenase (RuBisCO) 
are in direct contact with the intercellular air space that is connected to the atmosphere via stomatal pores in the epidermis. Hence, in $\mathrm{C} 3$ crops, rising $\mathrm{CO} 2$ increases net photosynthetic $\mathrm{CO} 2$ uptake, because RuBisCO is not $\mathrm{CO} 2$-saturated in today's atmosphere and because $\mathrm{CO} 2$ inhibits the competing oxygenation reaction, leading to photorespiration.

$\mathrm{CO} 2$-fertilization effects can include an increase in photosynthetic rate, reduction of transpiration rate through decreased stomatal conductance, higher water use efficiency (WUE) and a lower probability of water stress occurrence. As a consequence, crop growth and biomass production may increase by up to $30 \%$ for $\mathrm{C} 3$ plants at doubled ambient $\mathrm{CO} 2$; however, other experiments show biomass increases of only $10-20 \%$ under doubled $\mathrm{CO} 2$ conditions. In theory, at $25^{\circ} \mathrm{C}$, an increase in $\mathrm{CO} 2$ from the current $380-550 \mathrm{ppm}$ (air dry mole fraction), projected for the year 2050, would increase photosynthesis by $38 \%$ in C3 plants. In contrast, in C4 plants (e.g. maize and sorghum) RuBisCO is localized in the bundle sheath cells in which $\mathrm{CO} 2$ concentration is 3 to 6 times higher than atmospheric $\mathrm{CO} 2$.

Table 2. Percentage increases in yield, biomass and photosynthesis of crops grown at elevated CO2 (adapted from Long et al. 2006)

\begin{tabular}{|c|c|c|c|c|}
\hline Source & Rice & Soybean & Wheat & $\mathrm{C}_{4}$ crops \\
\hline \multicolumn{5}{|l|}{ Yield } \\
\hline Allen et al. (1987) & - & 26 & _- & - \\
\hline $\begin{array}{l}\text { Cure \& Acock } \\
\text { (1986) }\end{array}$ & 11 & 22 & 19 & 27 \\
\hline Kimball (1983) & 19 & 21 & 28 & - \\
\hline Enclosure studies & - & 32 & 31 & 18 \\
\hline FACE studies & 12 & 14 & 13 & $0^{*}$ \\
\hline \multicolumn{5}{|l|}{ Biomass } \\
\hline Allen et al. (1987) & - & 35 & - & - \\
\hline $\begin{array}{l}\text { Cure \& Acock } \\
\text { (1986) }\end{array}$ & 21 & 30 & 24 & 8 \\
\hline FACE studies & 13 & 25 & 10 & $0^{*}$ \\
\hline \multicolumn{5}{|l|}{ Photosynthesis } \\
\hline $\begin{array}{l}\text { Cure \& Acock } \\
\text { (1986) }\end{array}$ & 35 & 32 & 21 & 4 \\
\hline FACE studies & 9 & 19 & 13 & 6 \\
\hline
\end{tabular}

Indirect effects (also known as weather effects) are the effects of solar radiation, precipitation and air temperature. Keeping management the same, cereals yields typically decrease with increasing temperatures and increase with increased solar radiation. If water is limited, yields eventually decrease because of higher evapotranspiration. Precipitation will obviously have a positive effect when it reduces water stress but can also have a negative effect such as, for example, through water logging.

In addition to CO2, nitrogen (N) deposition is also expected to increase further (IPCC 2007) and it is known that increasing $\mathrm{N}$ supply frequently results in declining species diversity (Clark \& Tilman 2008). In a long-term open-air experiment, grassland assemblages planted with 16 species were grown under all combinations of ambient and elevated $\mathrm{CO} 2$ and ambient and elevated N. Over 10 years, elevated N reduced species diversity by $16 \%$ at ambient $\mathrm{CO} 2$ but by just $8 \%$ at elevated $\mathrm{CO} 2$.

\subsection{Plant breeding and climate change}

The most likely scenario within which plant breeding targets need establishing is the following:

- $\quad$. Higher temperatures, which will reduce crop productivity, are certain

- Increase in $\mathrm{CO} 2$ concentration is certain with both direct and indirect effects

- . Increasing frequency of drought is highly probable

- . Increase in the areas affected by salinity is highly probable

- Increasing frequency of biotic stress is also highly probable

Given this scenario, and given that plant breeding has been a success story in increasing yield (Dixon et al. 2006), plant breeding may help in developing new cultivars with enhanced traits better suited to adapt to climate change conditions using both conventional and genomic technologies (Habash et al. 2009). These traits include drought and temperature stress resistance; resistance to pests and disease -which continue to cause crop losses (Oerke 2006), salinity and water logging (Humphreys 2005). Breeding for drought resistance has historically been one of the most important and common objectives of several breeding programmes for all the major food crops in most countries (Ceccarelli et al. 2004, 2007). Opportunities for new cultivars with increased drought tolerance include changes in phenology or enhanced responses to elevated $\mathrm{CO} 2$.

With respect to water, a number of studies have documented genetic modifications to major crop species (e.g. maize and soybeans) that have increased their water-deficit tolerance (Cheikh et al. 2000), although this may not 
extend to a wide range of crops. In general, too little is known currently about how the desired traits achieved by genetic modification perform in real farming and forestry applications (Sinclair \& Purcell 2005).

Thermal tolerances of many organisms have been shown to be proportional to the magnitude of temperature variation they experience: lower thermal limits differ more among species than upper thermal limits (AddoBediako et al. 2000). Therefore, a crop, such as barley, which has colonized a wide diversity of thermal climates, may harbour enough genetic diversity to breed successfully for enhanced thermal tolerance.

Soil moisture reduction due to precipitation changes could affect natural systems in several ways. There are projections of significant extinctions in both plant and animal species. Over 5000 plant species could be impacted by climate change, mainly due to the loss of suitable habitats. By 2050, the extent of the Fynbos Biome (Ericaceaedominated ecosystem of South Africa, which is an International Union for the Conservation of Nature and Natural Resources crisis. The expected increase of biofuel monoculture production may lead to increased rates of biodiversity loss and genetic erosion. Another serious consequence of the loss of biodiversity has been the displacement of locally adapted varieties which may hold the secret of adaptation to the future climate (Ceccarelli \& Grando 2000; Sarker \& Erskine 2006; Fetien \& Bjørnstad 2009).

While it is estimated that there are 250000 plant species, of which about 50000 are edible, in fact not more than 250 are used - out of which 15 crops provide 0.9 of the calories in the human diet and three of them, namely wheat, rice and maize, provide $0.6 \%$. In these three crops, modern plant breeding has been particularly successful and movement towards genetic uniformity has been rapid - the most widely grown varieties of these three crops are closely related and genetically uniform (pure lines in wheat and rice and hybrids in maize). The major consequence of the dependence of modern agriculture on a small number of varieties for the major crops (Altieri 1995) is that the main sources of food are more genetically vulnerable than ever before, i.e. food security is potentially in danger. A number of plant breeders have warned that conventional plant breeding by continuously crossing between elite germplasm lines would lead to the extinction of diverse cultivars and non-domesticated plants(Vavilov 1992; Flora 2001; Gepts 2006; Mendum \& Glenna 2010) and climate change may exacerbate the collection sites at the time the collection was made, while the second is dynamic, because landraces and wild relatives are heterogeneous populations and, as such, they evolve and can generate continuously novel genetic variation.

Adaptive capacity in its broadest sense includes both evolutionary changes and plastic ecological responses. In the climate change literature, it also refers to the capacity of humans to manage, adapt and minimize impacts (Williams et al. 2008). All organisms are expected to have some intrinsic capacity to adapt to changing conditions; this may be via ecological (i.e. physiological and/or behavioral plasticity) or evolutionary adaptation (i.e. through natural selection acting on quantitative traits). There is now evidence in the scientific literature that evolutionary adaptation has occurred in a number of species in response to climate change both in the long term as seen earlier in the case of stomata (Woodward 1987) or over a relatively short term. Recently, Morran et al. (2009) used experimental evolution to test the hypothesis that outcrossing populations are able to adapt more rapidly to environmental changes than self-fertilizing organisms as suggested by Stebbins (1957), Maynard Smith (1978) and Crow (1992), explaining why the majority of plants and animals reproduce by outcrossing as opposed to selfing. The advantage of outcrossing is to provide a more effective means of recombination and thereby generating the genetic variation necessary to adapt to a novel environment (Crow 1992). The experiment of Morran et al. (2009) suggests that even outcrossing rates lower than $0 \cdot 05$, therefore comparable with those observed in selfpollinated crops such as barley, wheat and rice (outcrossing rates as high as 0.07 have been reported in barley (Marshall \& Allard 1970; Allard et al. 1972) and 0.035 in wheat (Lawrie et al. 2006) allowed adaptation to stress environments as indicated by a greater fitness, accompanied by an increase in the outcrossing rates.

During periods of drought, the yield of bulk populations increases over commercial cultivars selected under high input, but these yield advantages do not hold when conditions are agronomically favorable (Danquah \& Barrett 2002). The positive effect on the control of persistent and flexible diseases of increasing genetic diversity has been shown with the use of multiline (Wolfe 1985; Garrett \& Mundt 1999;Zhu et al. 2000). A genetically diverse bulk population allows for adaptation to disease through the establishment of a self-regulating plantpathogen evolutionary system (Allard 1990). 


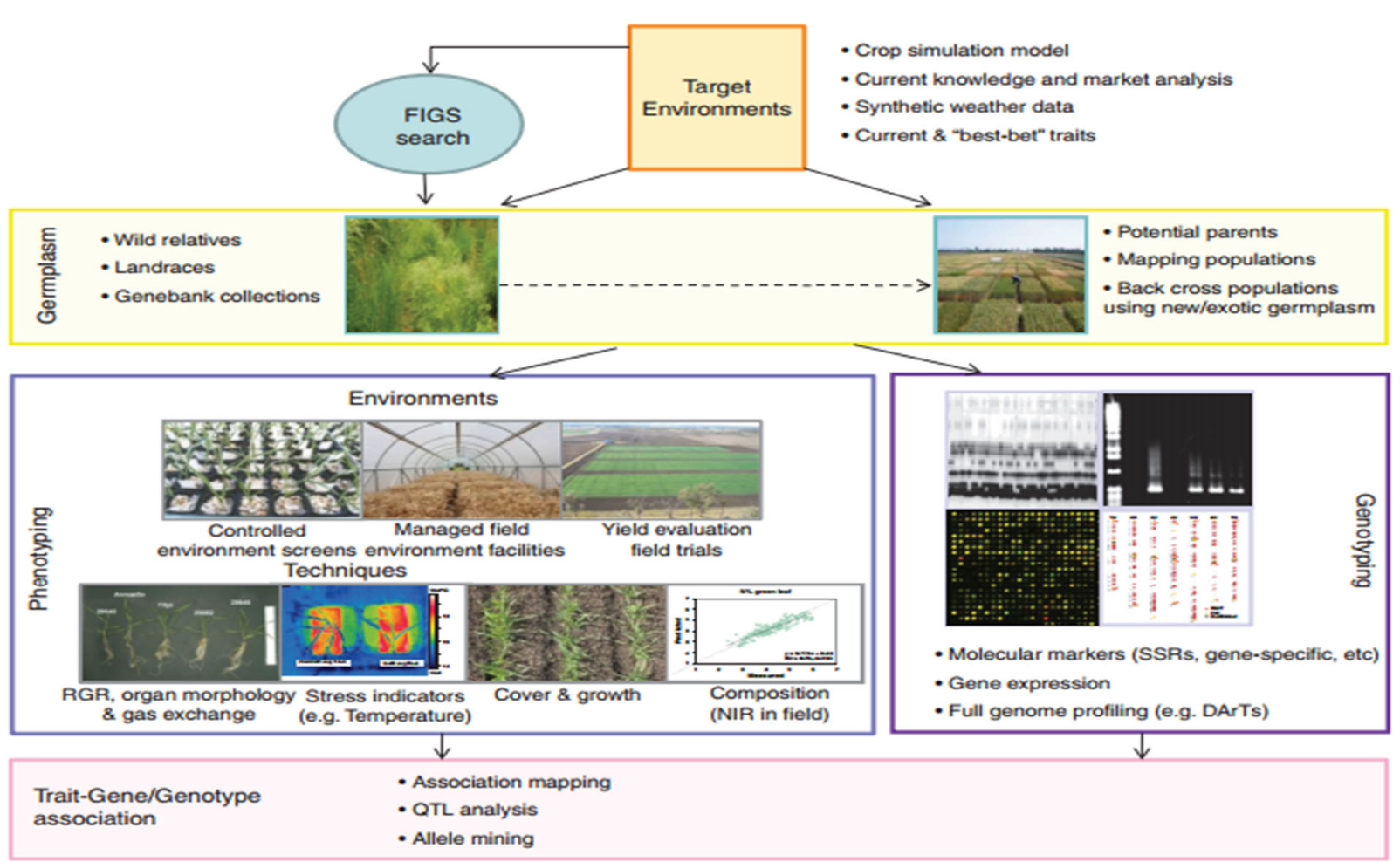

Figure 2. Combination of Breeding Approaches Needed to Advance Yield in a Changing Climate (Reynolds et al 2009). N.B FIGS: Focused Identification of Germplasm Strategy,DARTs: Diversity arrays traits and NIR:Near Isogenic Race.

\section{CONCLUSION}

Climate change is now unequivocal, particularly in terms of increasing temperature, increasing $\mathrm{CO} 2$ concentration, widespread melting of snow and ice and rising global average sea level, while the increase in the frequency of drought is very probable but not as certain. The climate changes that are occurring at present will have - and are already having - an adverse effect on food production and food quality with the poorest farmers and the poorest countries most at risk. The adverse effect is a consequence of the expected or probable increased frequency of some abiotic stresses such as heat and drought, and of the increased frequency of biotic stresses (pests and diseases). In addition, climate change is also expected to cause losses of biodiversity, mainly in more marginal environments.

Plant breeding has addressed both abiotic and biotic stresses. Strategies of adaptation to climate changes may include a more accurate matching of phenology to moisture availability using photoperiod-temperature response, increased access to a suite of varieties with different duration to escape or avoid predictable occurrences of stress at critical periods in crop life cycles, improved water use efficiency and a re-emphasis on population breeding in the form of evolutionary participatory plant breeding to provide a buffer against increasing unpredictability.

\section{REFERENCE}

FETIEN ABAY \& BJØRNSTAD, A. (2009). Specific adaptation of barley varieties in different locations in Ethiopia. Euphytica 167, 181-195.

HABASH, D. Z., KEHEL, Z. \& NACHIT, M. (2009). Genomic approaches for designing durum wheat ready for climate change with a focus on drought. Journal of Experimental Botany 60, 2805-2815

MORRAN, L. T., PARMENTER, M. D. \& PHILLIPS, P. C. (2009). Mutation load and rapid adaptation favour outcrossing over self-fertilization. Nature 462, 350-352

NELSON, G. C., ROSEGRANT, M. W., KOO, J., ROBERTSON, R., SULSER, T., ZHU, T., RINGLER, C., MSANGI, S., PALAZZO, A., BATKA, M., MAGALHAES, M., VALMONTE-SANTOS, R., EWING, M. \& LEE, D. (2009). Climate Change: Impact on Agriculture and Costs of Adaptation. Food Policy Report. Washington, DC: International Food Policy Research Institute.

Reynolds MP, Manes Y, Izanloo A, Langridge P (2009) Phenotyping for physiological breeding and gene discovery in wheat. Ann Appl Biol 155:309-20.

ATKInSON, M. D., KETTLEWELL, P. S., POUlTON, P. R. \& HOLlinS, P. D. (2008). Grain quality in the Broadbalk.

BATES, B. C., KUNDZEWICZ, Z. W., WU, S. \& PALUTIKOF, J. P. (2008). Climate Change and Water. 
Technical Paper of the Intergovernmental Panel on Climate Change. Geneva, Switzerland: IPCC Secretariat. BROWN, M. E. \& FUNK, C. C. (2008). Food security under climate change. Science 319, 580-581.

LOBELL, D. B., BURKE, M. B., TEBALDI, C., MASTRANDREA, M. D., FALCON, W. P. \& NAYLOR, R. L. (2008). Prioritizing climate change adaptation needs for food security in 2030. Science 319, 607-610.

WILLIAMS, S. E., SHOO, L. P., ISAAC, J. L., HOFFMANN, A. A. \& LANGHAM, G. (2008). Towards an integrated framework for assessing the vulnerability of species to climate change.

BEERLING, D. J. (2007). The Emerald Planet: How Plants Changed Earth's History. Oxford, UK: Oxford University Press.

CECCARELLI, S. \& GRANDO, S. (2007). Decentralized-participatory plant breeding: an example of demand driven research. Euphytica 155, 349-360.

IPCC (INTERGOVERNMENTAL PANEL ON CLIMATE CHANGE). (2007). Climate Change 2007. The Physical Science Basis: Summary for Policymakers. Geneva, Switzerland: IPCC Secretariat.

DIXON, J., NALLEY, L\& AQUINO, P. (2006). Adoption and economic impact of improved wheat varieties in the developing world. Journal of Agricultural Science, Cambridge 144, 489-502.

SARKER, A. \& ERSKINE, W. (2006). Recent progress in the ancient lentil. Journal of Agricultural Science, Cambridge 144, 19-29.

LONG, S. P., AINSWORTH, \& ORT, D. R. (2006). Food for thought: lower-than-expected crop yield stimulation with rising CO2 concentrations. Science 312, 1918-1921.

OERKE, E.-C. (2006). Crop losses to pests. Journal of Agricultural Science, Cambridge 144, 31-4.

HUMPHREYS, M. O. (2005). Genetic improvement of forage crops - past, present and future. Journal of Agricultural Science, Cambridge 143, 441-448.

SINCLAIR, T. R. \& PURCELL, L. C. (2005). Is a physiological perspective relevant in a 'genocentric' age? Journal of Experimental Botany 56, 2777-2782.

DANQUAH, E. Y. \& BARRETT, J. A. (2002). Grain yield in composite cross five of barley: Effects of natural selection. Journal of Agricultural Science, Cambridge 138, 171-176.

BEERLING, D. J., OSBORNE, C. P. \& CHALONER, W. G. (2001). Evolution of leaf-form in land plants linked to atmospheric CO2 decline in the Late Palaeozoic era. Nature 410,352-354.

DEMENOCAL, P. B. (2001). Cultural responses to climate change during the late Holocene. Science 292, 667673.

ADDO-BEDIAKO, A., CHOWN, S. L. \& GASTON, K. J. (2000). Thermal tolerance, climatic variability and latitude. Proceedings of the Royal Society of London B 267, 739-745.

CECCARELLI, S. \& GRANDO, S. (2000). Barley landraces from the Fertile Crescent: a lesson for plant breeders.In Genes in the Field: On-farm Conservation of Crop Diversity (Ed. S. B. Brush), pp. 51-76. Boca Raton, FL:IDRC

GRAY, J. E., HOLROYD, G. H.,WOODWARD, F. I., SCHUCH, W. \& HETHERINGTON, A. M. (2000). The HIC signaling pathway links CO2 perception to stomatal development. Nature 408, 713-716.

PRETORIUS, Z. A., SINGH, R. P., WAGOIRE, W. W. \& PAYNE, T. S. (2000). Detection of virulence to wheat stem rust resistance gene Sr31 in Puccinia graminis. f. sp. tritici in Uganda. Plant Disease 84, 203.

ZHU, Y., CHEN, H., FAN, J., WANG, Y., LI, Y., CHEN, J., FAN, J. X., YANG, S., HU, L., LEUNG, H., MEW, T. W., TENG, P. S., WANG, Z. \& MUNDT, C. C. (2000). Genetic diversity and disease control in rice. Nature 406, 718-722.

ALTIERI, M. A. (1995). Agroecology: The Science of Sustainable Agriculture. Boulder, CO: Westview Press.wheat experiment and the winter North Atlantic oscillation. Journal of Agricultural Science, Cambridge $146,541-549$.

AVILOV, N. I. (1992). Origin and Geography of Cultivated Plants. Cambridge, UK: Cambridge University Press.

ALLARD, R. W. (1990). The genetics of host-pathogen coevolution: implications for genetic resource conservation. Journal of Heredity 81, 1-6Proceedings of the National Academy of Sciences, USA 69, 30433048.

ROSEN, A. M. (1990). Environmental change at the end of early Bronze Age Palestine. In L'urbanisation de la Palestine à l'âge du Bronze ancien (Ed. P. De Miroschedji), pp. 247-255. Oxford, UK: BAR International.

WOODWARD, F. I. (1987). Stomatal numbers are sensitive to increases in CO2 from preindustrial levels. Nature 327, 617-618.

WOLFE, M. S. (1985). The current status and prospects of multiline cultivars and variety mixtures for disease resistance. Annual Review of Phytopathology 23, 251-273.

ALLARD, R. W., BABBEL, G. R., CLEGG, M. T. \& KAHLER,A. L. (1972). Evidence for coadaptation in Avena barbata. 